\title{
Lichen Substances Prevent Lichens from Nutrient Deficiency
}

\author{
Markus Hauck • Karen Willenbruch • \\ Christoph Leuschner
}

Received: 6 October 2008 /Revised: 5 December 2008 / Accepted: 8 December 2008 / Published online: 17 January 2009

(C) The Author(s) 2009. This article is published with open access at Springerlink.com

\begin{abstract}
The dibenzofuran usnic acid, a widespread cortical secondary metabolite produced by lichen-forming fungi, was shown to promote the intracellular uptake of $\mathrm{Cu}^{2+}$ in two epiphytic lichens, Evernia mesomorpha and Ramalina menziesii, from acidic, nutrient-poor bark. Higher $\mathrm{Cu}^{2+}$ uptake in the former, which produces the depside divaricatic acid in addition to usnic acid, suggests that this depside promotes $\mathrm{Cu}^{2+}$ uptake. Since $\mathrm{Cu}^{2+}$ is one of the rarest micronutrients, promotion of $\mathrm{Cu}^{2+}$ uptake by lichen substances may be crucial for the studied lichens to survive in their nutrient-poor habitats. In contrast, study of the uptake of other metals in E. mesomorpha revealed that the intracellular uptake of $\mathrm{Mn}^{2+}$, which regularly exceeds potentially toxic concentrations in leachates of acidic tree bark, was partially inhibited by the lichen substances produced by this species. Inhibition of $\mathrm{Mn}^{2+}$ uptake by lichen substances previously has been demonstrated in lichens. The uptake of $\mathrm{Fe}^{2+}, \mathrm{Fe}^{3+}, \mathrm{Mg}^{2+}$, and $\mathrm{Zn}^{2+}$, which fail to reach toxic concentrations in acidic bark at unpolluted sites, although they are more common than $\mathrm{Cu}^{2+}$, was not affected by lichen substances of E. mesomorpha.
\end{abstract}

Keywords Lichenized Ascomycetes · Dibenzofurans · Depsides $\cdot$ Metal homeostasis $\cdot$ Copper

\section{Introduction}

Lichens are known for their ability to cope with extreme environments. They can adapt to extreme temperatures,

\footnotetext{
M. Hauck $(\triangle) \cdot$ K. Willenbruch $\cdot$ C. Leuschner

Department of Plant Ecology, Albrecht von Haller Institute

of Plant Sciences, University of Göttingen,

Untere Karspüle 2,

37073 Göttingen, Germany

e-mail: mhauck@gwdg.de
}

drought, inundation, salinity, high concentrations of heavy metals (Nash 2008), or even survive in outer space (Sancho et al. 2007). Another outstanding character of lichens is tolerance to nutrient-poor environments. Mechanisms that enable a lichen to deal with shortages of nutrients have been poorly scrutinized, although most cannot compete with vascular plants at well-supplied sites.

Lichen substances are a chemically diverse group of more than 800 mostly phenolic compounds largely specific to lichen-forming fungi. They recently were shown to specifically inhibit the intracellular uptake of toxic amounts of transition metals, whereas other metals absent at toxic concentrations from the environment of the lichen could pass (Hauck 2008). Due to the high specificity of the role of lichen substances in metal tolerance, we tested the hypothesis that the opposite effect, the promotion of the uptake of metals needed as micronutrients, may be realized in the lichen symbiosis in nutrient-poor environments. We studied $\mathrm{Cu}^{2+}$ uptake in lichens with usnic acid (UA), a widespread cortical dibenzofuran in lichen-forming fungi. This example was selected, as $\mathrm{Cu}^{2+}$ is, after Mo, usually the rarest micronutrient in the microhabitats of epiphytes of nutrient-poor bark (Gauslaa 1995). Moreover, UA forms complexes with $\mathrm{Cu}^{2+}$ (Takani et al. 2002). We selected two UA-producing epiphytic lichens characteristic of nutrientpoor, acidic bark, Evernia mesomorpha Nyl. and Ramalina menziesii Taylor. The former lichen produces the depside divaricatic acid (DA) in addition to UA, whereas the latter lichen only synthesizes UA.

\section{Methods and Materials}

Lichens were collected in Mongolia (Khentey, Eroo, Khonin Nuga; E. mesomorpha) and the USA (Oregon, Benton County, Porter Lake; R. thrausta). Thalli were 
stored in air-dry condition at $-18^{\circ} \mathrm{C}$ in the dark before the experiment. After thawing, extracellular lichen substances were extracted with acetone from one half of the lichen thalli. Samples were submersed in acetone $(4 \times 10 \mathrm{~min})$. The efficacy of this treatment at removing lichen substances was controlled by high-pressure liquid chromatography by using a reverse-phased column and gradient elution. Viability of lichen thalli was controlled by measuring the chlorophyll fluorescence yield $\left(\Phi_{2}\right)$ of light-adapted samples at photosystem II after the acetone treatment with a PAM-2100 chlorophyll fluorometer (Walz, Effeltrich, Germany).

Five pieces of the fruticose thalli of up to 5 -cm length were used in each replicate sample and combined on a Petri dish with a moist cellulose filter. For acclimatization, Petri dishes with thalli were stored in a growth chamber for 2 days at $80 \% \mathrm{RH}$, a day temperature (for $13 \mathrm{~h}$ daily) of $13^{\circ} \mathrm{C}$ with a photon flux density of $30 \mu \mathrm{mol} \mathrm{m} \mathrm{m}^{-2} \mathrm{~s}^{-1}$, and a night temperature of $10^{\circ} \mathrm{C}$. Lichens then were exposed for $30 \mathrm{~min}$ to $50 \mathrm{ml}$ of $20 \mu \mathrm{M} \mathrm{CuCl}$, which is typical of the microhabitats of the studied lichens under unpolluted conditions on a shaker at $\mathrm{pH}$ 4. The uptake of $\mathrm{Fe}^{2+}, \mathrm{Fe}^{3+}$, $\mathrm{Mg}^{2+}, \mathrm{Mn}^{2+}$, and $\mathrm{Zn}^{2+}$ from chloride salt solutions was studied in E. mesomorpha in comparison. These salts were applied at a higher concentration $(100 \mu \mathrm{M})$ than $\mathrm{CuCl}_{2}$ because their concentrations in stemflow, throughfall, and bark, which form important nutrient sources for epiphytes, are higher than that of $\mathrm{Cu}^{2+}$ (Gauslaa 1995). Moreover, these metals cause less membrane damage than $\mathrm{Cu}^{2+}$, which would impair the experiment. After exposure to the metal solution, the extra- and intracellular cations were sequentially extracted. For this purpose, samples were shaken with deionized water $(2 \times 20 \mathrm{ml})$ to remove free apoplastic ions. Metal ions bound to hydroxylic or carboxylic exchange sites of the cell wall were exchanged by shaking samples with $\mathrm{NiCl}_{2}(2 \times 20 \mathrm{ml})$. Afterwards, all samples were shaken with acetone $(2 \times 20 \mathrm{ml})$ to remove metal ions potentially bound to extracellular lichen substances. Samples were dried at $105^{\circ} \mathrm{C}$, homogenized, and digested with $65 \% \mathrm{HNO}_{3}$ in order to analyze intracellular concentrations of $\mathrm{Cu}, \mathrm{Fe}, \mathrm{Mg}, \mathrm{Mn}$, or $\mathrm{Zn}$ with atomic absorption spectrometry (AAS Vario 6, Analytik Jena, Germany). The measuring error inherent to the AAS amounted to $<1 \%$.

Statistical analyses were computed with SAS 6.04 software (SAS Institute Inc., Cary, NC, USA). All data are given as arithmetic means \pm standard error and were tested for normal distribution with the Shapiro-Wilk test. Samples were tested for significant differences with Student's $t$ test for pairwise comparisons.

\section{Results and Discussion}

Samples containing their natural content of lichen substances took up significantly more $\mathrm{Cu}^{2+}$ than acetoneextracted samples, both in E. mesomorpha ( $t$ test, $P \leq 0.01$, $d f=4)$ and in $R$. menziesii $(P \leq 0.05$; Fig. $1 \mathrm{a}, \mathrm{b})$. The promotion of metal uptake was highly specific for $\mathrm{Cu}^{2+}$. Uptake of $\mathrm{Fe}^{2+}, \mathrm{Fe}^{3+}, \mathrm{Mg}^{2+}$, and $\mathrm{Zn}^{2+}$ in E. mesomorpha was not influenced by lichen substances. Intracellular uptake of $\mathrm{Mn}^{2+}$ was even reduced $(P \leq 0.05$; Fig. 1c). This makes sense, as peak concentrations of $\mathrm{Mn}^{2+}$ leached from the canopy are known to limit the abundance of lichens on acidic bark (Hauck and Paul 2005), as has been found in conifers and some broad-leaved trees such as beech and oak. Hence, reduced uptake broadens the ecological niche of lichens, although $\mathrm{Mn}^{2+}$ is essential in minor amounts. Partial inhibition of $\mathrm{Mn}^{2+}$ uptake by lichen substances is already known from epiphytic lichens at $\mathrm{Mn}^{2+}$-rich sites (Hauck 2008).

Stronger promotion of $\mathrm{Cu}^{2+}$ uptake in E. mesomorpha than in R. menziesii (Fig. 1) suggests that DA in addition to UA could contribute to $\mathrm{Cu}^{2+}$ uptake. However, although members of the same family (Parmeliaceae), both lichens differ in their morphology, which is also likely to affect element uptake. Complex formation of $\mathrm{UA}$ and $\mathrm{Cu}^{2+}$ in the $\mathrm{pH}$ range preferred by UA-producing lichens $(\mathrm{pH} 3.5-6$;
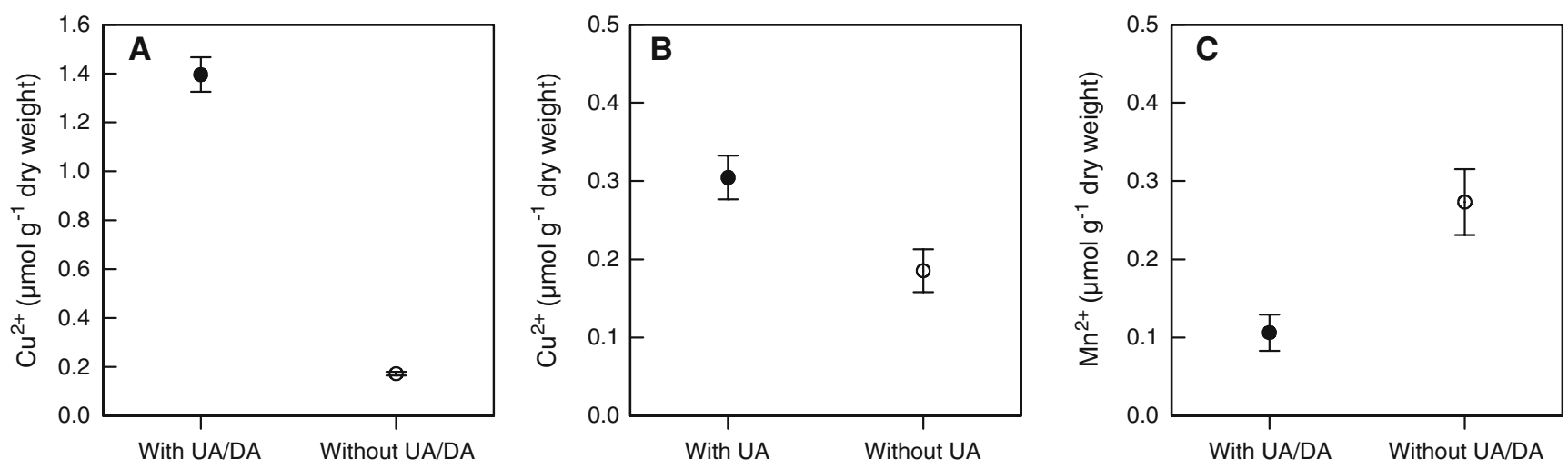

Fig. 1 Intracellular concentrations of $\mathrm{Cu}^{2+}$ in $\mathbf{a}$ E. mesomorpha and $\mathbf{b}$ R. menziesii and $\mathbf{c} \mathrm{Mn}^{2+}$ in E. mesomorpha with and without their natural content of lichen substances after exposure to $\mathrm{CuCl}_{2}$ or $\mathrm{MnCl}_{2}$ solution for $30 \mathrm{~min}(N=5)$. Error bars indicate standard error 
Takani et al. 2002; Hauck and Jürgens 2008; Hauck et al. 2009) suggests that these complexes are involved in the observed promotion of $\mathrm{Cu}^{2+}$ uptake. Whether such lipophilic complexes directly cross the phospholipid membrane (as proven for uncomplexed UA; Abo-Khatwa et al. 1996; Hauck and Jürgens 2008) or $\mathrm{Cu}^{2+}$ ions are transferred to transporters is unclear. Given the multitude of compounds and their widespread ability to interact with metal ions (Hauck and Huneck 2007), it is likely that promotion of nutrient uptake will be seen in other lichen symbioses. Recent UV-spectroscopic studies in yellow and orange lichen substances, including UA, suggested that promotion of metal uptake by lichen substances might be widespread (Hauck et al. 2009). Lichen compounds that occur in lichens of nutrient-poor sites form complexes with metal ions precisely at the $\mathrm{pH}$ ranges preferred by the respective lichens. Lichens growing under $\mathrm{pH}$ conditions, at which lichen substances do not bind to metals, are limited to substrata rich in mineral nutrients (Hauck et al. 2009). Research is necessary to elucidate the extent to which lichen substances are involved in the metal homeostasis of lichens.

Acknowledgements The work was funded by a grant of the German Science Foundation to M. Hauck (DFG Ha 3152/8-1). We thank Prof. Dr. Bruce McCune, Oregon State University, Corvallis, OR, USA for collecting $R$. menziesii.

Open Access This article is distributed under the terms of the Creative Commons Attribution Noncommercial License which permits any noncommercial use, distribution, and reproduction in any medium, provided the original author(s) and source are credited.

\section{References}

Abo-Khatwa, A. N., Al-Robai, A. A., and Al-Jawhari, D. A. 1996. Lichen acids as uncouplers of oxidative phosporylation of mouse-liver mitochondria. Nat. Toxins 4:96-102.

GAUSLAA, Y. 1995. The Lobarion, an epiphytic community of ancient forests threatened by acid rain. Lichenologist 27:59-76.

HAUCK, M. 2008. Metal homeostasis in Hypogymnia physodes is controlled by lichen substances. Environ. Pollut. 153:304-308.

HAUCK, M., and HuNECK, S. 2007. Lichen substances affect metal adsorption in Hypogymnia physodes. J. Chem. Ecol. 33:219-223.

HAUCK, M., and JÜRGENS, S.-R. 2008. Usnic acid controls the acidity tolerance of lichens. Environ. Pollut. 156:115-122.

HAUCK, M., and PAUL, A. 2005. Manganese as a site factor for epiphytic lichens. Lichenologist 37:409-423.

Hauck, M., JÜrgens, S.-R., Willenbruch, K., Huneck, S., and LEUSCHNER, C. 2009. Dissociation and metal-binding characteristics of yellow lichen substances suggest relationship to site preferences of lichens. Ann. Bot. 103:13-22.

NASH, T. H. (ed.) 2008. Lichen Biology. 2nd edn. Cambridge University Press, Cambridge.

Sancho, L. G., De la Torre, R., Horneck, G., Ascaso, C., los Rios, A., Pintado, A., Werzchos, J., and Schuster, M. 2007. Lichens survive in space: results from the 2005 LICHENS experiment. Astrobiol. 7:443-454.

Takani, M., Yajima, T., Masuda, H., and Yamauchi, O. 2002. Spectroscopic and structural characterization of copper(II) and palladium(II) complexes of a lichen substance usnic acid and its derivatives. Possible forms of environmental metals retained in lichens. J. Inorganic Biochem. 91:139-150. 